\title{
Principles of formation of a vehicle's braking system complex diagnostics
}

\author{
Michat Liss ${ }^{1,}{ }^{*}$, Roman Zinko², Oleh Polishchuk ${ }^{3}$, Marcin Łukasiewicz ${ }^{1}$ and German $R$. \\ B etancur ${ }^{4}$ \\ IUTP University of Science and Technology, Faculty of Mechanical Engineering, Al. prof. S. \\ Kaliskiego 7, Bydgoszcz, 85-796, Poland \\ ${ }^{2} \mathrm{~L}$ viv Polytechnik National University, St.B andery Street 12 , L viv, 79013, Ukraine \\ ${ }^{3} \mathrm{~K}$ hmel nitsky National U niversity, Instytutska Street 11, K hmelnytskyi, 29000, Ukraine \\ ${ }^{4}$ EAFIT U niversity, Facoulty of M echanical Engineering, Carrera $49 \mathrm{~N} 7$ sur 50, Colombia
}

\begin{abstract}
On-board diagnostics of technical condition of the brake system elements provide control during the inter-control period of operation. The use of $A B S$ requires further development of on-board diagnostic tools based on the development of new diagnostic methods using multilevel structural and effect schemes, primarily in terms of efficiency parameters. Increase of the information content by increasing the number of measured kinematic parameters and improving the algorithms for generating control signals for the brake system actuators showed effectiveness of diagnostics. To implement diagnostics of technical state of the brake system elements on board of a vehicle, a structural diagram of a diagnostic device, which uses telecommunication means of connection with an expert system and a voltage strain gauge in the coupling device of a truck has been proposed. It is advisable to carry out in-depth element-by-element diagnostics under bench conditions, with the maximum possible exclusion of random factors affecting the process. To summarize all information about the state of the vehicle@ braking system, it is necessary to use an expert system.
\end{abstract}

\section{Introduction}

Active vehicle safety is determined not only by its technical equipment, but also by the serviceability of technical condition of its elements during operation.

A significant number of road accidents (up to 70\%) occur when drivers use emergency braking mode and up to $60 \%$ are accompanied by a loss of stability and controllability. It is generally recognized that one of the most promising ways to solve the problem of increasing active vehicle safety during braking is the use of anti-lock braking systems (ABS). Equipping of vehicles with anti-lock braking systems (ABS) has exceeded $80 \%$ for passenger vehicles produced in Europe. Recognizing this fact, legislatures of different countries are now encouraging car manufacturers to implement $A B S$. Thus, the introduction of the "Federal M otor V ehicle Safety Standard" N 0.121 (FM VSS 121 "Pneumatic brake systems") [1], N o. 105 (F M V SS "Hydraulic brake systems") [2] became a serious stimulus in the U nited States for the development of anti-lock braking systems for pneumatic bus and trucks brakes. In Western Europe, there are two international regulatory documents: Directive $71 / 320$ of the EEC countries and UNECE Regulation No. 13, which regulate timing of installation of $A B S$ in all categories of vehicles with the exception of passenger cars. In accordance with these documents, from October 1, 1991 on the territory of the EEC countries, operation of vehicles of category N 3 (trucks with a gross weight of more than 16 $\mathrm{t}$ ) and $\mathrm{MZ}$ (intercity buses with a gross weight of more than $12 \mathrm{t}$ ), as well as trailers and semi-trailers of category 04 (full weight of more than 10 tons), not equipped with ABS was

* Corresponding author: michal.liss@utp.edu.pl 
forbidden. In Japan, these requirements have come into force since 1992, in the USA since 1993.A ccording to EEC Directive 71/320, all buses and trucks with a gross weight of up to $3.5 \mathrm{t}$, manufactured after January 1, 1998, must be equipped with ABS.

\section{Presenting main material}

Control of technical condition during the operation of a vehicle is carried out periodically at the next maintenance after a certain mileage or once a year. On the other hand, the failure of elements of the braking system of a vehicle and especially the ABS entails serious consequences. ABS manufacturers equip a self-monitoring system that checks the health of electrical circuits and the signal level. There are cases when the ABS self-diagnosis system does not signal a malfunction.

The above-mentioned dictates urgent need to improve on-board diagnostic tools for technical state of the brake system elements, capable of obtaining, at least in the first approximation, objective information for the driver about the state of the brake system as a whole and the quality of the work process being carried out during the inter-control period [3-7]. Such on-board diagnostics should be based on braking dynamism on the basis of the implemented deceleration [8-12]. Further development of on-board diagnostics tools can be seen in the creation of intelligent systems based on the developed structural and effect schemes [13-16]. Table 1 presents an example of structural and effect scheme, developed for pneumatic brakes with ABS.

The tendency to improve on-board diagnostics of technical state of the brake system elements is on the way of increasing information content by increasing the number of measured kinematic parameters and improving al gorithms for generating control signals for actuators (brakes, engine, transmission drive and analytical base of the algorithm mathematical models of the movement of wheeled vehicles) [17- 18].

The main task of all algorithms of modern on-board technical condition diagnostics is directly or indirectly narrowed down to determining the force factors in contact of the wheel with the supporting surface, therefore, their direct measurement will simplify the control algorithm, and thereby increase the efficiency of the automatic systems and reduce their cost.

Table 1. Structural and effect scheme for A BS elements diagnostics of a vehicle with pneumatic braking system.

\begin{tabular}{|c|c|c|c|}
\hline Sub-system & \multicolumn{3}{|c|}{ ABS ELEMENTS } \\
\hline Structural & \multicolumn{2}{|c|}{ MODULATOR VALVE RESPONSE TIME } & NO SENSOR SIGNAL \\
\hline $\begin{array}{l}\text { Cause of } \\
\text { malfunction }\end{array}$ & $\begin{array}{l}\text { Skewed or } \\
\text { deformed guide } \\
\text { bushings }\end{array}$ & $\begin{array}{c}\text { Broken sensor wire. } \\
\text { Oxidation of contacts. } \\
\text { Wheel sensors ground } \\
\text { fault. }\end{array}$ & $\begin{array}{l}\text { B roken sensor wire. } \\
\text { Oxidation of contacts. W heel } \\
\text { sensors ground fault. }\end{array}$ \\
\hline $\begin{array}{c}\text { Diagnostic } \\
\text { indications of } \\
\text { the } 1^{\text {st }} \text { level }\end{array}$ & \multicolumn{2}{|c|}{$\begin{array}{c}\text { Deterioration of A BS performance, vehicle } \\
\text { control and braking stability }\end{array}$} & $\begin{array}{c}\text { No signals for changing the } \\
\text { angular vel ocity available. } \\
\text { ABS shuts down }\end{array}$ \\
\hline $\begin{array}{l}\text { Diagnostic } \\
\text { indications of } \\
\text { the } 2^{\text {nd }} \text { level }\end{array}$ & $\begin{array}{c}\text { Increase of the } \\
\text { average realized } \\
\text { amplitude of wheel } \\
\text { angular decel eration } \\
\text { oscillations }\end{array}$ & $\begin{array}{l}\text { Increase of total } \\
\text { duration of the } \\
\text { braking phase }\end{array}$ & $\begin{array}{l}\text { Increase of total duration of } \\
\text { the braking phase }\end{array}$ \\
\hline $\begin{array}{l}\text { Diagnostic } \\
\text { parameters }\end{array}$ & \multicolumn{2}{|c|}{$\begin{array}{c}\text { A verage realized amplitude of wheel angular } \\
\text { deceleration oscillations, duration of the } \\
\text { braking phase }\end{array}$} & $\begin{array}{l}\text { Time the wheel is in the skid } \\
\text { state, average realized slip, } \\
\text { angular acceleration and } \\
\text { deceleration of the wheel }\end{array}$ \\
\hline
\end{tabular}


Table extended 1. Structural and effect scheme for ABS elements diagnostics of a vehicle with pneumatic braking system.

\begin{tabular}{|c|c|c|c|c|c|c|c|c|}
\hline Sub-system & \multicolumn{8}{|c|}{ ABS ELEMENTS } \\
\hline $\begin{array}{c}\text { Structural } \\
\text { parameters }\end{array}$ & \multicolumn{2}{|c|}{$\begin{array}{l}\text { THRESHOLD } \\
\text { DECREASE }\end{array}$} & \multicolumn{2}{|c|}{$\begin{array}{l}\text { CHANGE OF THE } \\
\text { THRESHOLD OF } \\
\text { CONTROL UNIT } \\
\text { ADJUSTMENT }\end{array}$} & \multicolumn{4}{|c|}{ THRESHOLD INCREASE } \\
\hline $\begin{array}{c}\text { Cause of } \\
\text { malfunction }\end{array}$ & & & $\begin{array}{l}\text { Change } \\
\text { of the } \\
\text { temperatu } \\
\text { re regime } \\
\text { of } \\
\text { electronic } \\
\text { controls }\end{array}$ & $\begin{array}{l}\text { Failure of } \\
\text { hermeticity } \\
\text { of the } \\
\text { control unit }\end{array}$ & & & & \\
\hline $\begin{array}{c}\text { Diagnostic } \\
\text { indications } \\
\text { of the } 1^{\text {st }} \\
\text { level }\end{array}$ & $\begin{array}{r}\text { Deteri } \\
\text { vehicle's } \\
\text { and brakin } \\
{[S \mathrm{X}] \leq} \\
\text { dyr }\end{array}$ & $\begin{array}{l}\text { tion of } \\
\text { trollability } \\
\text { tability at } \\
\text { braking } \\
\text { ics }\end{array}$ & & & $\begin{array}{r}\text { Increase } \\
\text { term } \\
\text { peri }\end{array}$ & hort- & $\begin{array}{l}\text { Dete } \\
\text { veh } \\
\text { an }\end{array}$ & $\begin{array}{l}\text { oration in } \\
\text { e control } \\
\text { oraking } \\
\text { bility }\end{array}$ \\
\hline $\begin{array}{l}\text { Diagnostic } \\
\text { indications } \\
\text { of the } 2^{\text {nd }} \\
\text { level }\end{array}$ & $\begin{array}{l}\text { Increase } \\
\text { of } A B S \\
\text { regulation } \\
\text { frequency }\end{array}$ & $\begin{array}{l}\text { Increase } \\
\text { of total } \\
\text { duration } \\
\text { of the } \\
\text { braking } \\
\text { phase }\end{array}$ & & & $\begin{array}{c}\text { Increase } \\
\text { of } \\
\text { average } \\
\text { realized } \\
\text { wheel } \\
\text { slip }\end{array}$ & $\begin{array}{l}\text { Reduc } \\
\text { the av } \\
\text { real } \\
\text { ang } \\
\text { accel } \\
\text { of the }\end{array}$ & $\begin{array}{l}\text { on of } \\
\text { rage } \\
\text { ed } \\
\text { lar } \\
\text { ation } \\
\text { heel }\end{array}$ & $\begin{array}{c}\text { Increase } \\
\text { of } \\
\text { average } \\
\text { realized } \\
\text { wheel } \\
\text { decelerati } \\
\text { on }\end{array}$ \\
\hline $\begin{array}{c}\text { Diagnostic } \\
\text { parameters }\end{array}$ & $\begin{array}{r}\text { A verao } \\
\text { angular a } \\
\text { the wh } \\
\text { regulatio }\end{array}$ & $\begin{array}{l}\text { ealized } \\
\text { eration of } \\
\text {, ABS } \\
\text { requency }\end{array}$ & & & $\begin{array}{r}\text { Timet } \\
\text { aver } \\
\text { acceler }\end{array}$ & $\begin{array}{l}\text { Wheel } \\
\text { e realiz } \\
\text { on and } \\
\text { W }\end{array}$ & $\begin{array}{l}\text { in the } \\
\text { d slip, } \\
\text { eceler } \\
\text { eel }\end{array}$ & $\begin{array}{l}\text { kid state, } \\
\text { igular } \\
\text { on of the }\end{array}$ \\
\hline
\end{tabular}

The construction of a diagnostic algorithm is preceded by the development of a block diagram of structural and effect relationships in the following chain: the diagnosed object unit - system, mechanism - element - structural parameter - malfunction - external sign (symptom) - diagnostic parameter. Each link determines the level of search or technological step aimed at detecting a fault. In a generalized form, the stages of development of the diagnostic al gorithm are presented in Table 2.

Table 2. Stages of elaboration of a generalized diagnostics algorithm.

\begin{tabular}{|c|c|c|c|}
\hline $\begin{array}{l}\text { Stages of } \\
\text { algorithm } \\
\text { elaboration }\end{array}$ & $\begin{array}{l}\text { Search } \\
\text { level }\end{array}$ & Structural and effect connection & $\begin{array}{c}\text { M ethod of } \\
\text { implementation }\end{array}$ \\
\hline ANALYSIS & $\begin{array}{l}1 \\
2 \\
3 \\
4 \\
5 \\
6\end{array}$ & $\begin{array}{l}\text { Determination of vehicle's general technical } \\
\text { condition } \\
\text { Control of vehicle's main units and systems } \\
\text { Search for malfunctions in units, mechanisms } \\
\text { and systems of individual units } \\
\text { Control of components of the diagnosed } \\
\text { mechanism } \\
\text { Control of couplings and elements with the } \\
\text { lowest values of reliability indicators in } \\
\text { operation } \\
\text { Control of structural parameters }\end{array}$ & $\begin{array}{l}\text { Instrumental and } \\
\text { technical }\end{array}$ \\
\hline
\end{tabular}




\begin{tabular}{|c|c|l|c|}
\hline SY NTHESIS & 7 & $\begin{array}{l}\text { Control of possible malfunctions of elements } \\
\text { and couplings } \\
\text { Determination of the list of external indications, } \\
\text { by manifestation of which a specific } \\
\text { malfunction is determined } \\
\text { Determination of a preliminary list of possible } \\
\text { diagnostic parameters }\end{array}$ & $\begin{array}{c}\text { Informational and } \\
\text { analytical }\end{array}$ \\
\hline
\end{tabular}

To implement diagnostics of technical state of the brake system elements on board of a vehicle, a block diagram of the device for diagnostics shown in Fig. 1 has been proposed.

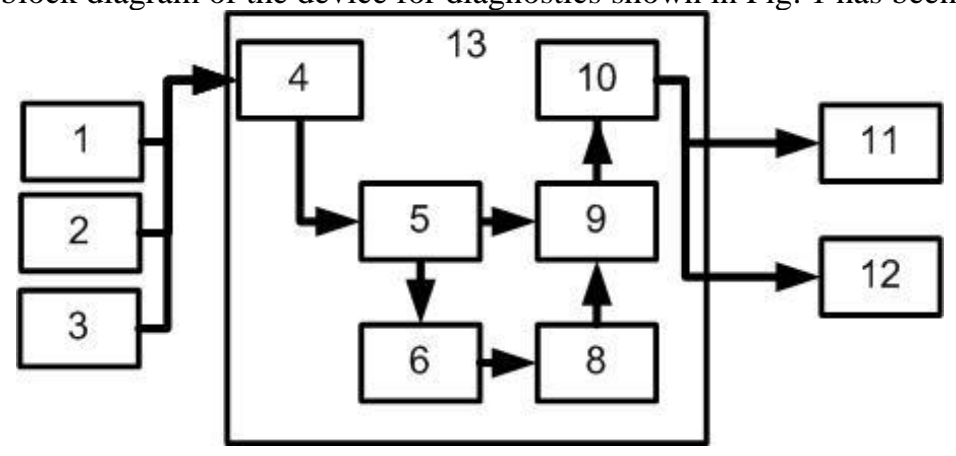

Fig. 1. Structural scheme of a device for brakes diagnostics on board of a vehicle.

The device contains a vehicle deceleration sensor 1 , a pressure sensor 2 in the brake drive and a voltage load sensor 3 in the coupling device connected to a specialized computing unit for inter-connected processing of braking parameters 13 , connected to the display unit 11 of the diagnostics result and the telecommunication unit 12.

The computing unit 13 consists of a unit 4 for comparison of the input parameters of the vehicle's deceleration values, pressure in the brake actuator, and a stress strain gauge in the coupling device, a threshold device 5 according to the value of the ratio of the vehicle's deceleration signal to pressure in the brake actuator, unit 8 for extracting the maximum value of the ratio, a two-channel memory 9 and a module for comparing data with reference values for this vehicle 10. Outputs of deceleration sensors 1 , pressure in the brake drive 2 , voltage strain gauge in the coupling device 3 are connected to the block 6 for comparing input parameters. In this case, the output of block 4 for comparing the input parameters is connected to the input of the threshold device 5, the outputs of which are connected to the block 6 for extracting the maximum value of the ratio and the two-channel storage device 9 , the output of block 8 for extracting the maximum value of the ratio is connected to the second input of the two-channel storage device 9, the output of the two-channel storage device 9 is connected to the module 10 for comparison with reference values for this vehicle. The output of the latter is connected to the display unit 11 and the telecommunication unit 12.

Current level of development of telecommunication technologies allows to effectively transfer large amounts of information in real time, which creates opportunities for remote diagnostics and control of vehicles, including the one in automatic mode [19-24]. In this case, diagnostics are carried out by a remote server on the basis of accumulated and operational data.

Following special standards, two main methods of diagnostics of brake systems are used - road and bench [25]. They have controlled parameters:

1. Road test: braking distance; steady-state deceleration; braking stability; braking system response time; the slope of the road on which the vehicle must stay motionless; 
2. Bench tests: total specific braking force; the coefficient of irregularity (relative irregularity) of braking forces of the axle wheels, and for a truck. there is also an additional coefficient of compatibility of truck's links and asynchrony of the response time of the brake drive.

In real operating conditions, the braking process occurs with a significant variation in the characteristics of external conditions, in particular, fluctuations in the clutch coefficient both in the longitudinal and transverse directions, which cannot but affect accuracy of the diagnostics. The latter circumstance necessitates monitoring technical condition of the elements of the brake system under fixed and reproducible external conditions, which is achieved with bench diagnostics.

Full-fledged brake diagnostics is really possible only by bench tests. Currently, there are many types of stands and instruments that use different methods of braking qualities measurement: static, power, inertial, platform inertial, power roller, roller stands, devices for measuring vehicle deceleration during road tests.

Static power stands. Static power stands for diagnosing vehicle brakes look like roller or platform devices, which are designed to turn the "breakdown" of a braked wheel and measure the applied force. These stands have different drives: hydraulic, pneumatic or mechanical. It is possible to measure the braking force when the wheel is suspended or when it is supported on smooth rollers. The disadvantage of the static method for diagnosing brakes is the approximate results, as a result of which the conditions of the actual dynamic braking process are not reproduced.

Inertial roller stands. Inertial roller stands use rollers that can be driven by an electric motor or vehicle engine. If in such case rollers driven by an electric motor are used, then driving wheels of the vehicle force the rollers of the stand to rotate, and via them, using a mechanical transmission, the front (driven) wheels. When the vehicle is installed on an inertial stand, the linear speed of the wheels increases from 50 to $70 \mathrm{~km} / \mathrm{h}$ and brakes sharply, separating, at the same time, all carriages of the stand by turning off electromagnetic couplings. In addition, inertia forces appear in the contact area of the wheels with the rollers (belts) of the stand, opposing the braking forces. After a period of time, rotation of the stand rollers and the vehicle's wheels ceases. The distance that each wheel of the vehicle travels during this time (or the angular deceleration of the roller) will be equivalent to braking distances and braking forces. To calculate the braking distance, rotation frequency of the stand rollers set with the counter, also according to their rotation time, measured by a stopwatch, and the deceleration - by an angular decelerometer is used.

The method, embodied by an inertial roller stand, creates braking conditions for the vehicle that are as close to real as possible. However, due to the high cost of the stand, poor safety, laboriousness and significant expenditure of time required for diagnostics, it is unreasonable to use stands of this type for diagnostics at auto enterprises and during state technical inspection.

Power roller stands. Power roller stands with the use of wheel-to-roller clutch forces measure braking forces during its rotation at a speed of 2,10 kilometers per hour. The wheels are turned by an electric motor. The braking forces are calculated from the reactive moment arising on the stator of the motor-reducer stand when the wheels are braking. Roller brake testers provide sufficiently accurate results of brake systems testing. When passing again, they can create conditions (first, the speed of rotation of the wheels), completely similar to the previous ones, which is ensured by the exact setting of the initial braking speed by an external drive. Moreover, when testing on power roller brake stands, measurement of the so-called "ovality" is provided - an assessment of the unevenness of the braking forces per wheel revolution, that is, the entire braking surface is examined. When tested on roller brake testers, with application of external pressure (from the brake testers), 
the physical braking pattern does not break. The braking system receives energy from the outside even though the vehicle does not have kinetic energy.

Table 3 shows a comparative analysis of the three types of stands for diagnostics of a vehicle's brake system.

Table 3. Comparative table of diagnostics stands.

\begin{tabular}{|c|c|c|c|c|}
\hline No & Criterion & $\begin{array}{c}\text { Power platform } \\
\text { stands }\end{array}$ & $\begin{array}{c}\text { Roller braking } \\
\text { stands }\end{array}$ & $\begin{array}{c}\text { Inertial platform } \\
\text { stand }\end{array}$ \\
\hline 1 & Cost & Low & A verage & High \\
\hline 2 & $\begin{array}{c}\text { A ccuracy of } \\
\text { measurements }\end{array}$ & Low & High & High \\
\hline 3 & $\begin{array}{c}\text { Validity of diagnostic } \\
\text { information }\end{array}$ & Low & Low & High \\
\hline 4 & Safety of operation & A verage & High & Low \\
\hline 5 & $\begin{array}{c}\text { Time consumption for } \\
\text { diagnostics }\end{array}$ & A verage & A verage & High \\
\hline
\end{tabular}

To summarize all information about the state of the vehicle@ braking system, it is necessary to use expert systems [26]. There are two generations of expert systems.

Computer systems that can only repeat the logical conclusion of an expert are usually referred to as the first generation. The knowledge here is presented the following way:

a) the knowledge of the system is only the knowledge of an expert, experience of accumulating knowledge is not provided;

b) methods of knowledge representation made it possible to describe only static subject areas;

c) knowledge representation models are focused on simple areas.

Expert systems belonging to the second generation are called partner systems, or amplifiers of human intellectual abilities $[27,28]$. Their common distinguishing features are the ability to learn and develop, i.e. evolve. K nowledge representation in second generation expert systems is as follows:

a) not superficial knowledge is used, but deeper ones. Subject area addition is possible;

b) ES can solve the problems of a dynamic database of the subject area of use, which will reduce the diagnostic time and costs.

The expert system for A BS and ESP diagnostics has the following structure [16]:

- knowledge acquisition subsystem - designed to add new rules to the knowledge base and modify existing ones;

- the knowledge base is a set of facts and a set of rules obtained from experts and introduced from special and reference literature;

- analysis subsystem - implements the reasoning process based on the knowledge base and working set - a dialogue processor - consists of a series of multiple choice questions;

- inference subsystem - implements the analysis results in a human-readable representation.

The aim of ES is to derive some given fact, which is called a target statement. The system operation is a sequence of steps, at each of which a certain rule is selected from the base, which is applied to the current contents of the working set. The cycle ends when the target statement is deduced or refuted $[29,30]$. The cycle of the expert system is otherwise called logical inference. Logical inference can occur in many ways, of which the most common are forward-ordering and reverse-ordering. The direct order of inference is from the facts that are in the working set to the conclusion. If such conclusion can be found, then it is entered into the working set. Direct inference is often called data driven inference. 
Taking into account the peculiarities of functioning of a vehicle's braking system with $A B S$, diagnostics should be carried out in a comprehensive manner, both by means of onboard diagnostics in the inter-control period, using telecommunication means of connection, and by bench and road methods based on the expert system (Fig. 2).

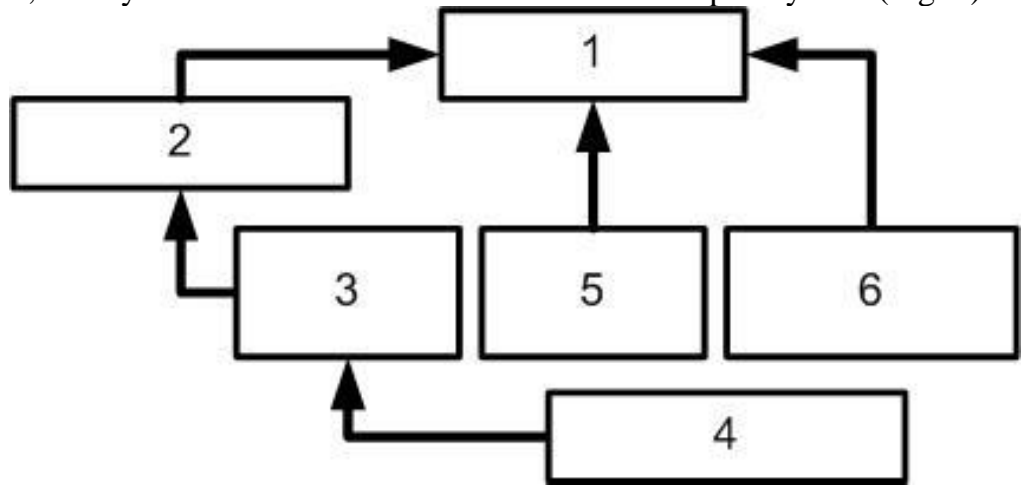

Fig. 2. Complex diagnostics of a braking system of a vehicle's with ABS: 1 - Expert system; 2 Telecommunication means of connection 3 - O n-board diagnostics system 4 - B raking system diagnostics 5 - Stand diagnostics 6 - Road testing

\section{Conclusions}

- on-board diagnostics of the technical state of the brake system elements provide control during the inter-control period of operation;

- the use of ABS requires further development of on-board diagnostic tools based on the development of new diagnostic methods using multilevel structural and effect schemes, primarily in terms of efficiency parameters;

- increase of the information content by increasing the number of measured kinematic parameters and improving the algorithms for generating control signals for the brake system actuators showed effectiveness of diagnostics;

- for the implementation of diagnostics of the technical state of the brake system elements on board of a vehicle, a structural diagram of the device for diagnostics has been proposed. It uses telecommunication means of connection with the expert system and a voltage strain gauge in the coupling device of the truck;

- it is advisable to carry out in-depth element-by-element diagnostics under bench conditions, with the maximum possible exclusion of random factors affecting the process;

- to summarize all information about the state of a vehicle@ braking system, it is necessary to use an expert system.

\section{References}

1. FMVSS 105, "Hydraulic Brake Systems" The National Highway Traffic Safety Administration (NHTSA) requires

2. FMVSS 121, "Air Brake Systems" The National Highway Traffic Safety Administration (NHTSA) requires

3. M. Bulgakov, S. Shuklynov, A. U zhva, D. Leontiev, V. V erbitskiy, M. A melin and 0. Volska, Mathematical model of the vehicle initial rectilinear motion during moving uphill: 24th Slovak-Polish International Scientific Conference on M achine M odelling and Simulations, (2019) 
4. V. Bogomolov, V. K limenko, D. L eontiev, L. Ryzhyh, O. Smyrnov and M. K holodov, Impruving the brake control effectiveness of vehicles equipped with a pneumatic brake actuator, Science \& Technique, 19 (1): 55-62, (2020)

5. R. Zinko, Efficiency of international automobile carriages, Zinko R. Monography, LA P LA M BERT A cademic Publishing, p. 164, (2018)

6. A. A. Revin, V. V. Kotov, V. V. Erontayev, Diagnostics of a vehicle's pneumatic braking system with ABS according to the parameters of the working process, Izvestiya vuzov, M echanical engineering, no 7, p. 26-31, (2007)

7. V.A. K im, M ethodology for creating systems of active safety of vehicles based on the analysis of forces, M ogilev, B elorus, p. 347, (2003)

8. A. A. Revin, Theory of operational properties of cars and trucks with A BS in braking mode, monograph, V olgSTU, V olgograd, RPK "Polytechnic", p. 372, (2002)

9. R. V. Zinko, L. V. Kraynik, O. Z. Gorbay, Basics of constructive synthesis and dynamics of special cars and technological machines, monograph, Lviv, L viv Polytechnic Publishing House, p. 344, (2019)

10. R. Emig, H. Goebels, and H. J. Schramm, Robert Bosch GmbH, A ntilock Braking Systems (A BS) for Commercial V ehicles - Status 1990 and Future Prospects, SAE Technical Paper Series 901177, (1990)

11. G. D. Kokorev, Improvement of the efficiency of the technical operation system of vehicles in agriculture based on the engineering-cybernetic approach, Doctoral dissertation, Technological Sciences, Ryazan, p. 483, (2014)

12. A. M. Matveev, G. A. Iovlev, V. S. Zorkov, On modern methods of assessing the economic efficiency of the use of agricultural machinery, Bulletin of the K urgan State A gricultural A cademy, no 4 (12), p. 5-8, (2014)

13. A. M. Dvoryankin, Artificial Intelligence. Knowledge bases and expert systems: textbook, Volgograd: RPK "Polytechnic", p. 140, (2002)

14. A. G. Kirillov, Operational management of vehicle performance based on the fuel consumption criterion with the use of new information technologies, $\mathrm{PhD}$ dissertation, Operation of motor transport, V ladimir State U niversity (VISU), p. 210, (2000)

15. V. A. Maksimov, V. V. Grebenyuk, R. I. Ismailov, A. V. Dunin, G. D. Knyazkov, S. V. Roschak, Diagnostic complex for operational accounting of parameters, Truck, no 1, p. 15-17, (2013)

16. R. Zinko, Morphological environment for technical systems investigation, Lviv Polytechnic Publishing, L viv, (2014)

17. G. D. Kokorev, A method for selecting a rational set of objects to be diagnosed, Bulletin of the Ryazan State Agrotechnological University named after P.A. Kostycheva, no. 1 (17), p. 61-64, (2013)

18. V.P. Kalyavin, Fundamentals of the theory of reliability and diagnostics, SPb Elmore, p. $172,(1998)$

19. P. Dzhelekarski, D. A lexiev, Initializing Communication to Vehicle OBD II System, Proc. Intern. Conf. ELECTRONICS, vol. 3, p. 46-52, (2005)

20. R. Malekian, N. R. M oloisane, L. Nair, B.T. Maharaj, U. A. K. ChudeO konkwo, Design and Implementation of a W ireless OBD II Fleet M anagement System, IEEE Sensors J., vol. 17, no. 4, p. 1154-1164, (2017)

21. H. Zhang, W. Kang, Design of the Data Acquisition System Based on STM 32, Procedia Comp. Sc., vol. 17, p. 222-228, (2013)

22. H. Si, Z. M. A ung, Position Data Acquisition from NMEA Protocolof Global Positioning System. IJ CEE, vol. 3, no. 3, p. 353-357, (2011)

23. Ł. Muślewski, R. Zinko, O. Polishchuk, Principles of Formation of a Vehicle's Remote Diagnostics, 18th International Conference Diagnostics of Machines and V ehicles, M A TEC W eb of Conferences, vol. 302, p.1-9, (2019) 
24. M. Bayly, S. Regan, M. Ilosking, Intelligent Transport system and Motorcycle safetytext, M onash University A ccident Research Center Report Documentation Page - 2006, A utomobile M echanics Text, 7th ed Delhi, K hanna Publishers, p. 728, (2001)

25. V. G. Dygalo, A. A. Revin, Virtual-physical technology of laboratory tests of active safety systems of vehicles: monograph, p. 316, V olgograd, (2006)

26. E .S. Larin, G. O. M elnikov, A. A. Revin, V. G. Dygalo, Expert system for diagnosing malfunctions of a vehicle's braking system with $A B S, 62$ nd open student scientific and technical conference SNTK M A M I, M oscow, p. 9-10, (2012)

27. Ł. Muślewski, M. Pająk, A. Grządziela, J. Musiał, A nalysis of vibration time histories in the time domain for propulsion systems of minesweepers Journal of Vibroengineering Vol. 17, Issue 3, pp. 1309-1316 (2015)

28. J. Musiał, S. Horiashchenko, R. Polasik, T. Kałaczyński, M. M atuszewski, M. Śrutek, A brasion W ear Resistance of Polymer Constructional M aterials for Rapid Prototyping and Tool-M aking Industry, Polymers, 12, 873 (2020)

29. T. Kałaczyński, M. Łukasiewicz, J. Musiał, R. Polasik, M. Szczutkowski , N. Dluhunovych, J. Wilczarska, T. Kasprowicz, A nalysis of the diagnostic potential research thermovision in the technical state of combustion engine injectors assessment, 24th International Conference Engineering Mechanics, Engineering M echanics, p. 1805-8248, Czech Republic, (2018)

30. M. Łukasiewicz, P. Falęcki, T. Kałaczyński, B. Żółtowski, J. Musiał , J. Wilczarska, R. Kostek: A nalysis of the thermovision diagnostics potential in the light system elements, 24th International Conference Engineering Mechanics, Engineering M echanics, 24, p. 1805-8248, Czech Republic, (2018) 